\title{
Analysis of welding plans for the energy pipeline
}

\begin{abstract}
Standards requirements for welding plans for energy pipeline repairs are presented. Examples of welding plans for pipeline repair are presented. The usefulness of various forms of presenting welding plans was compared - in tabular form and in the point form. It was shown that regardless of the form of the welding plan, it facilitates control of both the course of the manufacturing process and the requirements set by the product standard.
\end{abstract}

Keywords: welding plan; pipeline; energetics

\section{Introduction}

Pipeline can be defined as a conduit or a conduit system consisting of elements that, when connected to each other in a pressure system, are used to transport liquids within the installation [1]. One of many types of pipelines found in industry are so-called energy pipelines, which term is used for pipelines transporting steam within the power unit (i.e. a unit composed of a steam boiler and a turbogenerator). Parameters of steam used to power the steam turbine in domestic system power plants reach about $28 \mathrm{MPa}$ and $610^{\circ} \mathrm{C}$ (boiler BB-2400 in Bełchatów Power Station), which means that both the production of such a pipeline and its operation is subject to many restrictions. It is not surprising, therefore, that these specific pressure devices, such as power pipelines, have been subject to technical supervision in accordance with the Regulation of the Council of Ministers of 7 December 2012 on the types of technical devices subject to technical supervision (Journal of Laws 2012 No. 0, item 1468), where they are defined as pipelines connecting the boiler with the turbogenerator. The device category defined by the legislator includes:

a) in the power unit:

1) a pipeline leading the fresh (originally superheated) steam from the superheater to the high-pressure turbine part, between the main steam stop valve or the boiler welded joint and the welded joint connecting the pipeline with the turbine quick-closing valve, without this valve;
2) a pipeline leading steam from the outlet of the high pressure turbine part to the superheater, between the welded joint connecting the pipeline with the back valve at the turbine outlet or the turbine outlet nozzle and the welded joint connecting the pipeline to the inlet port of the superheater;

3) a bypass pipeline, together with a reduction and cooling station, connecting the steam pipeline leading to the turbine, with the outlet steam pipeline from the high-pressure turbine part;

4) pipeline leading steam superheated from the boiler to the medium pressure part of the turbine with branches leading to steam station and safety valves, between the welded joint connecting the pipeline to the boiler outlet nozzle and the welded joint connecting the pipeline with the quick-closing valve part of the medium-pressure turbine;

5) branch pipes from the pipelines listed in point $1 \div 4$, to the first shut-off valve or safety equipment, together with these devices;

b) in the collector system:

1) pipeline between the steam outlet from the superheater and the collector or collectors;

2) collectors with connecting pipelines;

3) pipeline connecting the collector with the turbine;

4) branch pipes from those mentioned in point $1 \div 3$, including safety accessories or first shut-off fittings. 


\section{Legal conditions}

The newly built energy pipeline, as a pressure device, must meet the requirements resulting from the Pressure Directive PED 2014/68/EU (entered into force on July 19, 2016 replacing Directive $97 / 23 / E C$, implemented by the Regulation of the Minister of Development into Polish legislation [2]) so that it can be placed on the markets of the European Union. The starting point for defining the requirements are the operating parameters (maximum allowable pressure PS (in bars)), size (in the case of pipelines nominal diameter DN) and to which group the medium belongs (steam - gas - group 2). Having this data and using Table 7 (or rather chart 7 in Annex II of the PED Directive), it can be determined which of the three risk categories the pipeline is eligible for. The membership in the category shows which conformity assessment modules should be used by the Manufacturer (Compliance Scoreboard, Annex II of the PED Directive, Table I), which translates into specific requirements that must be met.

Most power pipelines belong to the third risk category, as according to the commentary on Table 7 (Fig. 1), if the pipeline is classified in category II, but the temperature of fluid in it is higher than 350 degrees Celsius, it should be considered as part of category III. What's more, the manufacturer has the right to choose a higher category than that shown in Table 7. Independent of the choice of category, the manufacturer must conduct a pipeline conformity assessment with the minimum requirements of the PED Directive, taking into account the assumed reference conditions. A notified body is supervised over the course of this process, the degree of involvement of which results from the adopted module/ combination of conformity assessment modules.

\section{Reference conditions}

The simplest way to create a pressure device that meets the requirements imposed by the PED Directive is the application of the product standard, which is harmonized with the Directive, i.e. the application of the harmonized product standard automatically ensures that the product meets the requirements of the Directive. With regard to newly manufactured industrial pipelines, the most commonly used harmonized standard in Europe is PN-EN 13480: 2017 "Metal industrial pipelines". This document comprehensively considers issues related to the production of the pipeline, i.e. materials, strength calculations, production and assembly, control, etc. It is worth paying attention to the unofficial seventh part of the standard - unofficial, published as Technical Report CEN/TR 13480-7 [3], a practical guide to the conformity assessment process.

Irrespective of the risk category under which the pipeline is subject, the next stage is to become acquainted with Annex III of the PED Directive describing the requirements resulting from individual conformity assessment modules. Depending on the selected module/module combination, the following requirements related to the production area can be distinguished:

- materials used to build the pipeline comply with material

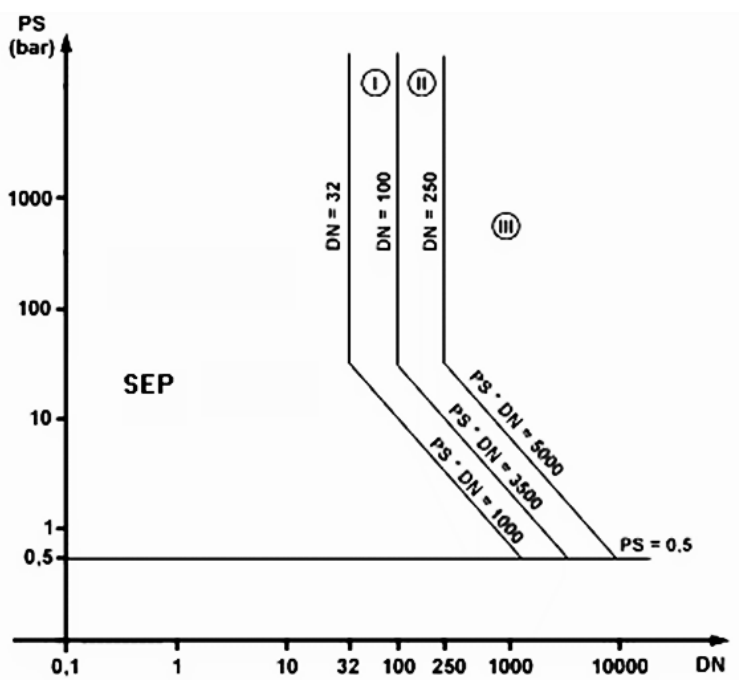

Fig. 1. Table 7 from Annex II to the PED 2014/68/EU Directive, on the basis of which the steam pipeline is classified as one of three hazard categories. SEP - Sound Engineering Practice

standards harmonized with the PED Directive, or admitted on the basis of the European approval of materials or the One-time Permission of Materials (PMA);

- having inseparable connection technologies approved by a notified unit:

- personnel making inseparable connections are certified by a notified unit or recognized third party organization to an appropriate extent;

- personnel performing non-destructive testing of inseparable connections are certified by a recognized third-party organization to an appropriate extent;

- plastic forming of elements (forming, bending) and heat treatment (if required) should be performed based on the technology approved by the notified unit.

It should be emphasized that the requirements set by the PED Directive are minimum requirements that must be met at the design and production stage. In practice, more stringent and more extensive reference conditions result from the adopted harmonized product or material standards. For example, in the fifth part of the standard, i.e. in PN-EN 13480-5 [4] concerning control and testing, there is Table 8.4.2 "Acceptance criteria for surface non-conformities", which, depending on the category to which the pipeline belongs, sets acceptable levels of quality $(B, C$ or $D)$ for visual tests of VT according to PN-EN ISO 5817 [5] for individual welding non-conformities defined by PN-EN ISO 6520-1 [6]. It turns out that in some cases, welding non-compliance in level B may not meet the requirements of the product standard. An example is the flooding (5011) - according to level B in PN-EN ISO 5817, the maximum permissible value cannot exceed $0.5 \mathrm{~mm}$ for welded thickness $\mathrm{t}>3 \mathrm{~mm}$, while the product standard PN-EN 13480-5 limits this value to $0.3 \mathrm{~mm}$ for a range of $6 \mathrm{~mm} \leq \mathrm{t}<16 \mathrm{~mm}$. Taking into account such nuances by the Manufacturer resulting from the product standard used is subject to detailed verification by a notified unit.

Table I. Conformity assessment table

\begin{tabular}{|c|c|l|}
\hline I & $=$ & module A \\
\hline II & $=$ & modules A2, D1, E1 \\
\hline III & $=$ & modules B (project type) + D, B (project type) + F, B (production type) + E, B (production type) + C2, H \\
\hline IV & $=$ & modules B (production type) + D, B (production type) + E, G, H1 \\
\hline
\end{tabular}


During the conformity assessment process there are inspections of representatives of the notified unit, during which the Manufacturer is asked to submit relevant documentation allowing to verify whether the activity complies with the approved design documentation, welding plan and control or product standard (e.g. during a visit to the workshop, verification a welder's certificate with a range of basic variations of the welding process instructions provided for the welded joint made by this welder). All as-built documentation, the scope of which was agreed at the design approval stage (protocols from required destructive and non-destructive testing, plastic processing, heat treatment after welding, welding log, list of materials used, list of authorized personnel together with certificates, etc.) is usually subject to thorough analysis from the notified unit. One of the key elements is the welding plan approved at the design control stage, which is verified with the actual welding log, which in effect allows to assess the correctness of the implementation of inseparable joints. This means that a clearly defined welding plan helps the Producer to organize the technological documentation, which is also very useful when checking the as-built documentation by the notified unit. On the example of the welding and inspection plan shown below, taken from industrial practice, it can be stated that the welding plan is enriched with a number of additional information, e.g. on heat treatment after welding, scope and type of non-destructive testing, hence it often becomes a Welding and Research Plan. Such a tabbed document with a corresponding isometric projection of the pipeline, on which individual welds are marked, allows to collect the most important information in one document.

Welding plans are also useful for the operation of pressure equipment. In the case of any repair or modernization of such a document, it is very easy to control the course of the repair and the necessary technological and quality documentation. Most often welding plans for renovation needs take a descriptive form, taking into account the technological aspects of repair, as in the example below.

\section{Technological welding plan}

Most often, this form is used for pipelines with smaller diameters and lengths, and thus a smaller number of welds. It is a popular solution in the case of pipelines covered by supervision when it is necessary to repair such a device - then the necessary formalities before commencement of works is to agree on the documentation of repair from UDT in accordance with the Technical Supervision Act [7]. In such cases, the welding plans describe step by step the course of repair together with the technological aspects of the process. |The following is a fragment of such a study on the example of a steam pipeline repair consisting in the replacement of a pipeline section. The direct cause of the repair were cracks detected in periodic tests in the area of heat affected zone connecting the drainage pipe to the pipeline. It was decided to cut out a part of the pipeline with a stub pipe and weld an insert in that place with the previously welded pipe stub: The pipeline repair course:

- cut a piece of pipeline $\varnothing 273 \times 14 \mathrm{~mm}$ in the places marked on the drawing;

- prepare the face of the cut pipe for welding by making bevels and whitewashing the inner and outer wall;

- in the place of the cut part of the pipeline, a measurement should be made, on the basis of which the insert dimension will be determined. The dimension of the insert must be reduced by approx. $5 \mathrm{~mm}$ per side in order to give room for the weld to be made;

- inserts prepared in this way (13CrMo4-5) should be inserted in place of cut out fragments, and then align and make tack welds;

- after tacking, inspect visually to detect any centric overloads;

- in the case of correctly made tack welds, it is possible to start welding the circumferential weld. For this purpose, preheat the material according to the instruction no. WPS $141 / 111$, according to which the penetration, filling and face should be made (combination of methods 141 and 111);

- the joint made in this way should be heat treated based on the PWHT-5.1 instruction, the result of which should be verified by measuring the hardness. The maximum permissible values are given in the PWHT working instructions;

- after finishing the heat treatment, perform a visual inspection of the machined joints $-100 \%$ range in accordance with the test standard PN-EN ISO 17637 [8] and weld assessment in accordance with the quality level specified in section 3.3.1.2 according to WUDT-UC-WO / 11 [9] ;

- after a positive VT test, perform surface tests using the MT method - a range of $100 \%$ of welded joints. The test shall be carried out in accordance with the test standard PN-EN 17638 [10], quality level according to PN-EN ISO 23278 [11] acceptance level 2.

- if the result of the MT test is positive, volumetric tests of the UT of the circumferential weld should be carried out. The test should be carried out in accordance with the PNEN 17640 test standard [12] and the assessment should be carried out according to PN-EN ISO 11666 [13] acceptance level 2.

Table II. Example of a plan for welding and testing of a steam pipeline

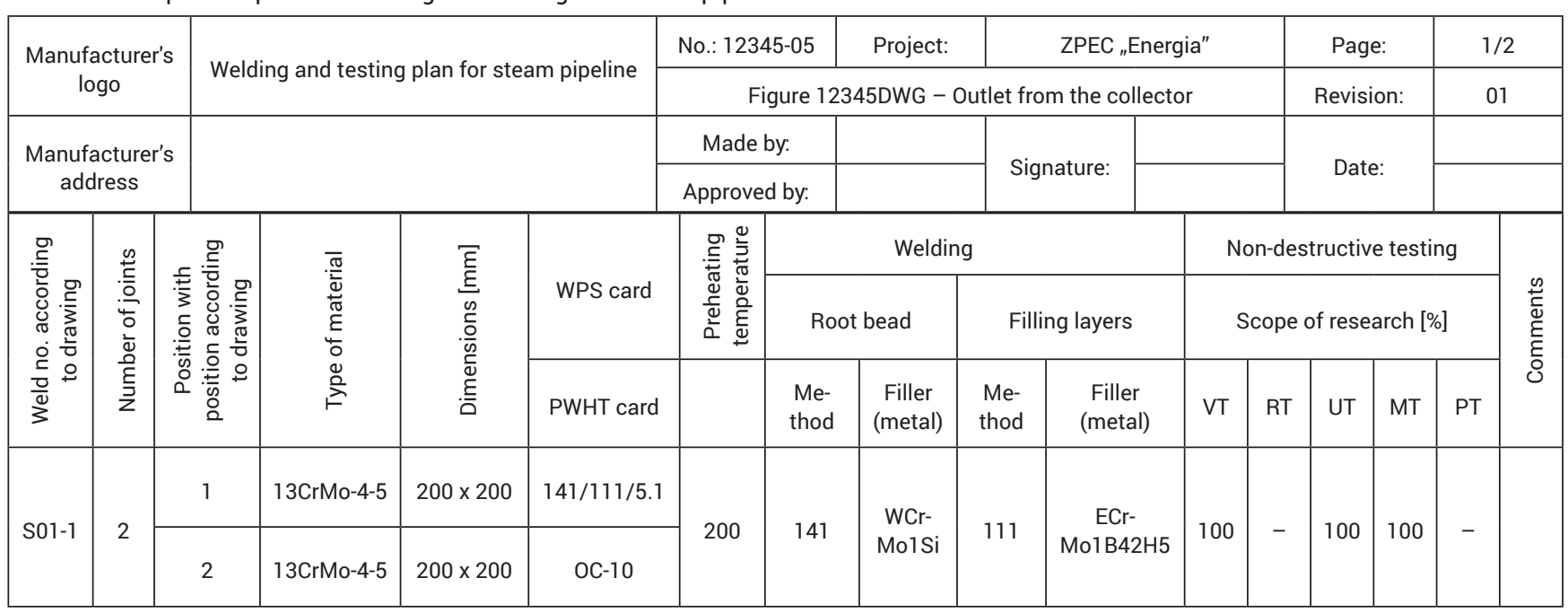


Such a descriptive welding plan has a certain advantage over the tabular welding plan, in that it accurately reflects the course of the repair process, i.e. the order of individual operations. The tabular welding plan presented in Table II only theoretically shows the order in which individual welds are performed, because in practice the technological aspects of the pipeline production process dictate the welding sequence. It is worth mentioning them, as this may have an impact on the decision regarding the choice of the form of the welding plan.

\section{The efficiency of welding power pipelines}

The operating parameters of power pipelines require the use of creep resistant steels due to high operating temperature and a simultaneous long-term internal pressure load. Such materials, energy steels (e.g. 13CrMo4-5, X10CrMoVNb91), require preheating and heat treatment after welding. Pipelines are prefabricated in the form of hot-bent knees or forged or welded tees. Therefore, the obvious tendency is to prepare as many components of the pipeline as possible in workshop conditions, which greatly facilitates the production of high quality weld [14]. As a result, at the workshop, individual prefabricates (firebricks, knees, tees) are welded together to the largest possible (due to logistics) part of the pipeline. The resulting so-called spools are then transported to the object on which they are merged with other spools or individual pipe fragments using assembly welds. This solution allows to reduce the number of assembly welds often carried out in forced positions and allows for a much better access to them for heat treatment after welding and non-destructive testing. The obvious limitation is the geometric shape and the weight of the spool, which affect the possibility of its transport between the manufacturing plant and the target and the transport itself inside the boiler room or engine room. It should be remembered that the pipeline is suspended and supported on various types of slings and supports, which both theoretically and practically allows the connection of individual spools not immediately forming the entire pipeline. What's more, the order in which the assembly welds are carried out is already influenced by the specific logistics inside the facility. The construction of a new pipeline usually coincides with a number of other works carried out simultaneously on the border of the boiler room and engine room, where several teams of different contractors are simultaneously present. Hence, it happens in the first place that the assembly welds, which at the moment are possible to perform due to the technology of construction and time synchronization with other robots ongoing on the site. This means that the welding and inspection plan is not a document that defines the order in which welds are made.

\section{Summary}

Both in the PED Directive and product standards there is no formal requirement to submit a welding plan. However, in practice, even with smaller constructions, a more or less extensive form of the welding plan is used because it facilitates control of the manufacturing process and control of the requirements of the product standard.

\section{References}

[1] Warunki Techniczne Urzędu Dozoru Technicznego WUDT-UC-RT/01 Wydanie 02.2017.

[2] Rozporządzenie Ministra Rozwoju z dnia 11 lipca 2016 r. w sprawie wymagań dla urządzeń ciśnieniowych i zespołów urządzeń ciśnieniowych (Dz.U. 2016 poz. 1036).

[3] CEN/TR 13480-7:2017 Metallic Industrial Piping - Part 7: Guidance on the use of conformity assessment procedures.

[4] PN-EN 13480-5:2017 Rurociągi przemysłowe metalowe - Część 5: Kontrola i badania.

[5] PN-EN ISO 5817:2014 Spawanie. Złącza spawane ze stali, niklu, tytanu i ich stopów (z wyjątkiem spawanych wiązką). Poziomy jakości według niezgodności spawalniczych.

[6] PN-EN ISO 6520-1:2009 Spawanie i procesy pokrewne - Klasyfikacja niezgodności spawalniczych w metalach - Część 1: Spawanie.

[7] Ustawa o Dozorze Technicznym z dn. 21 grudnia 2000 r. (Dz. U. z 2018, poz. 1351 z późn. zm.).
[8] PN-EN ISO 17637:2017 Badania nieniszczące złączy spawanych - Badania wizualne złączy spawanych.

[9] WUDT-UC-WO/11 Wydanie 02.2017 - Warunki Techniczne Urzędu Dozoru Technicznego - Urządzenia Ciśnieniowe - Wymagania Ogólne - Wytwarzanie / część 11 - Spawanie.

[10] PN-EN ISO 17638:2017 Badanie nieniszczące spoin - Badanie magnetyczno-proszkowe.

[11] PN-EN ISO 23278:2015 Badania nieniszczące spoin - Badania magnetyczno-proszkowe - Poziomy akceptacji.

[12] PN EN 17640:2018 Badania nieniszczące spoin - Badania ultradźwiękowe - Techniki, poziomy badania i ocena.

[13] PN EN ISO 11666:2018 Badania nieniszczące spoin - Badania ultradźwiękowe - Poziomy akceptacji.

[14] Słania J., Plany spawania. Teoria i praktyka (wyd. II), Agenda Wydawnicza SIMP Redakcja Przegląd Spawalnictwa (2015), Warszawa. 